\title{
Groundwater Occurrence from Hydrogeomorphological Study of Hard Rock Terrain of Part of Southwestern Nigeria
}

Pojavi Podzemne Vode Odkriti s Hidro-Geomorfološko Študijo Ozemlja Matičnih Kamnin v Jugozahodnem Delu Nigerije

\author{
Akanbi Olanrewaju Akinfemiwa ${ }^{1, *}$ \\ ${ }^{1}$ Department of Earth Sciences, Ajayi Crowther University Oyo, Oyo State, Nigeria \\ * olanrewajuakanbi@yahoo.com
}

\begin{abstract}
Studies of structural and hydrogeomorphological units (HGU) that are indicators of groundwater occurrence were carried out across an area extent of more than $700 \mathrm{~km}^{2}$ within the hard rock terrain of southwestern Nigeria. These studies integrated geological remote sensing techniques (RST) and geographical information system (GIS) methods to generate thematic maps that included elevation, drainage, lineaments and vegetation index for characterising the attributes of groundwater occurrence across the area.

The results revealed that the lineament system is mainly rectilinear with major trends of NNW-SSE and NE-SW on the gneiss, NW-SE and NE-SW on porphyritic granite and NNE-SSW, NW-SE and E-W on migmatite. The discharge zones in the area are the lowland terrains underlain by gneiss and amphibolite. Similarly, variably directional discontinuities that are related to rock contacts are equally laden with groundwater. Conversely, the recharge areas are the high-lying terrains characterised by higher fracture density and underlain by porphyritic granite and migmatite. Additionally, there are evidences of groundwater seepage along the major river channels. Therefore, besides the rock structures, landform is another crucial factor that guides groundwater distribution in the study area.
\end{abstract}

Key words: Hard rock, structures, hydrogeomorphological units, topography, groundwater occurrence

\section{Povzetek}

Pričujočo študijo strukturnih in hidro-geomorfoloških enot (HGU), ki nakazujejo pojave podzemne vode, so izvedli na več kakor $700 \mathrm{~km}^{2}$ velikem ozemlju matičnih kamnin v jugozahodni Nigeriji. Obsegala je geološke metode, metode daljinske detekcije (RST) in GIS, kar je omogočilo izdelavo tematskih kart nadmorske višine, povodij, prelomov in vegetacijskega indeksa, ki karakterizirajo navzočnost podzemne vode na ozemlju.

Raziskava kaže, da so prelomni sistemi v glavnem premočrtni s prevladujočimi smermi NNW-SSE in NE-SW v gnajsu, NW-SE in NE-SW v porfiritnem granitu in NNE-SSW, NW-SE in E-W v migmatitu. Pasovi iztekanja na proučevanem ozemlju so v niže ležečih območjih z gnajsom in amfibolitom v globini. Podzemna voda je vezana tudi na različne linearne nezveznosti na stikih med kamninami.

Nasprotno so pa napajalne površine na vzpetinah z značilno večjo gostoto razpok in navzočnostjo porfiritnega granita in migmatita. Iztekanje podzemne vode je dodatno moč opaziti v strugah glavnih rek. Mimo kamninske zgradbe je torej tudi krajinska oblikovanost dejavnik, ki odločilno vpliva na porazdelitev podzemne vode na proučevanem ozemlju.

Ključne besede: matična kamnina, zgradba, hidro-geomorfološe enote, topografija, pojavi podzemne vode 


\section{Introduction}

Crystalline basement rocks can neither store nor transmit water. Nonetheless, secondary water conduits generated from epigenetic geological events such as fractures and faults can develop within the impermeable crystalline rock units. Additionally, syngenetic structural discontinuities such as foliation and zones of rock contacts may equally be zones of water transmission in hard rock terrains, since they are zones of weakness that are more readily susceptible to weathering processes $[1,2]$. These rock discontinuities are the rock structural elements that are collectively regarded as lineaments when they are mappable over an area. Lineament can easily be mapped from the outcropping rock sections. However, in areas where there are no outcrops and where the hard rocks have been weathered or buried by recent deposit and regolith, the structures are most of the time invisible and undetectable, except by applying remote sensing techniques (RST).

The principle of remote sensing revolves around the physical attributes of natural ground objects in response to their distinguishing abilities to reflect, emit and absorb different intensities of radiation at different ranges of electromagnetic wavelength. The use of satellite imageries is one way of applying RST for groundwater investigation, and it has been found to be helpful for regional groundwater exploration of terrains with large area coverage $[3,4]$. Besides the geological setting of an area that has a strong bearing on groundwater prospect of the area, hydrogeomorphological units (HGU) in the form of thematic maps produced from appropriate satellite imageries are also vital in any groundwater study.

To a large extent, the application of remote sensing techniques (RST) in hydrogeomorphological studies of various landforms has been undertaken in more advanced nations $[5,6]$, and it is now becoming popular in developing nations of the African continent. For example, increase in the borehole success rate and reduction in the costs of groundwater exploration were linked to the application of RST for lineament interpretation in Ghana [7]. Nevertheless, there is need for more comprehensive approach in the application of RST to groundwater exploration.
This is more crucial in the hard rock terrains of southwestern Nigeria where groundwater potential is poor and the borehole success rate is just about $30 \%[2,8]$. Hence, besides lineament studies, the present work also applies RST to study other HGU that are indicators of groundwater such as landforms, surface water network pattern and vegetation index.

\section{Site Description and Geological Setting}

The study area occupies $711.17 \mathrm{~km}^{2}$ landmass area of the Ibarapa region within southwestern Nigeria on coordinates $\mathrm{N}^{\circ} 21^{\prime}$ to $\mathrm{N}^{\circ} 37^{\prime}$ and $\mathrm{E}^{\circ} 07^{\prime}$ to $\mathrm{E}^{\circ} 21^{\prime}$ (Figure 1). The major towns within the area are Igbo-Ora, Idere, Ayete and Tapa with a total population of 204,071 as per the last census conducted in 2006 [9]. With the human growth rate of $2.9 \%$ in Nigeria [10], it is expected that human population would have tripled in these communities. In respect of climatic conditions, the study area lies within the tropical climatic zone, which is marked by two distinct wet and dry seasons. The dry season extends from November to March with an average monthly precipitation of less than $25 \mathrm{~mm}$. The wet season peaks around June and September with the monthly rainfall exceeding $100 \mathrm{~mm}$. The total annual rainfall in the area ranges from 813 to $1853 \mathrm{~mm}$, whereas the annual temperature ranges from $24^{\circ} \mathrm{C}$ to $29^{\circ} \mathrm{C}$.

Like many cities, towns and rural settlements in Nigeria, Ibarapa town water supply scheme, which is largely sourced from surface water, has long been abandoned and houses are not connected with piped water facilities. Hence, for domestic water needs, and even for agricultural purposes, residents of Ibarapa areas rely on groundwater supply tapped from hundreds of hand-pump boreholes that were drilled for the communities across the area. However, even with these provisions, availability of potable water is still inadequate, largely due to the unsustainable yield of many of the functioning boreholes. This scenario is further complicated as a result of increasing human population in Nigeria that has an attending increasing demand on fresh water supply. This demand has made it mandatory to increase the present groundwater supply. However, the Ibarapa region is mainly underlain by crystalline basement rocks that ordinarily have little or no po- 


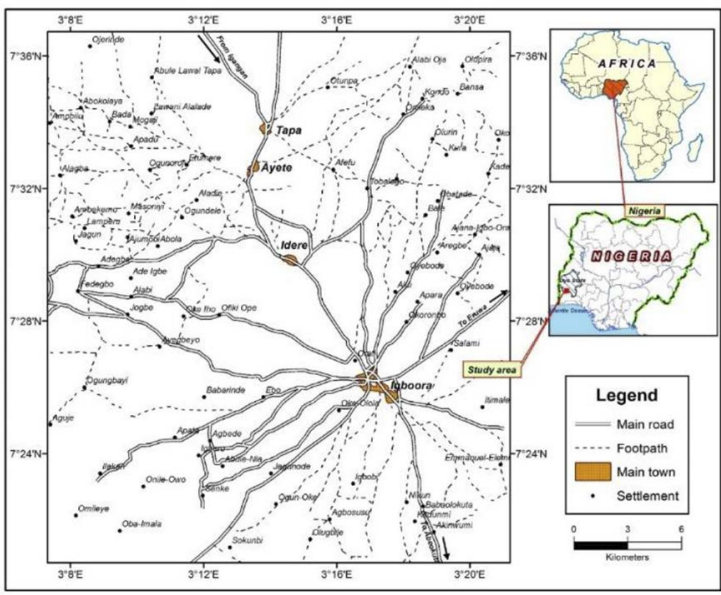

Figure 1: Location map of the study area.

tential for groundwater except where there are enough rock structures that are interconnected and development of a significant regolith thickness and/or occurrences of fractured bedrocks that aid groundwater transmission [11-13]. Therefore, the use of processed satellite imageries for geomorphological and structural studies of the Ibarapa region will provide insight into groundwater potential across this region, which is underlain by diverse crystalline rocks. The principal rock units are granite varieties that include coarse porphyritic granites and medium-grained granites, banded and augen gneissic rocks, amphibolite and migmatite. The distribution of the major rock units in the study area is shown in Figure 2. The outcrop exposures of porphyritic granite occur at the central part and occupy about one-third of the entire study. However, outcrops of the medium-grained granites are isolated and underlain comparatively much smaller area at the eastern part of the study area [2].

Amphibolite underlies most part of Igbo-Ora township and has massive and schistose varieties. The lineation trend ranges from $093^{\circ}$ to $124^{\circ}$, and the foliation dips between $38^{\circ} \mathrm{W}$ and $44^{\circ} \mathrm{W}$ [13] for the schistose variety. Banded and augen gneisses are foliated metamorphic rocks. The foliation of the banded gneiss trends northerly between $339^{\circ}$ and $360^{\circ}$ and dips vertically eastward close to Alagba at the NW region. The foliation dips between $68^{\circ} \mathrm{E}$ and $70^{\circ} \mathrm{E}$ at the WSW region and $37^{\circ} \mathrm{E}$ at the WNW area. Banded gneiss underlies most part of the western part

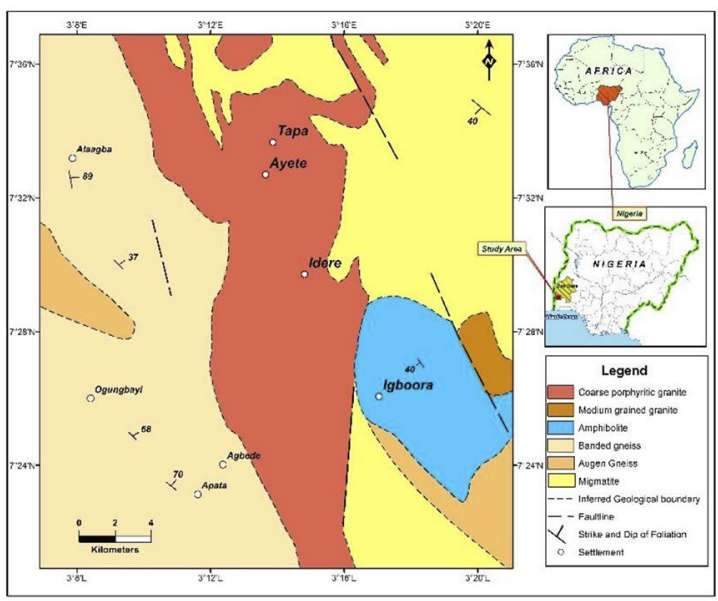

Figure 2: Geological map of the study area (modified after Weerawarnakula, 1986).

of the study area. Augen gneiss occupies small sections and is found as older rock units within the banded gneiss at the western and southeast parts of the study area. The migmatite is the oldest rock unit across the study area, and just like banded gneiss and porphyritic granite, migmatite also has an extensive area coverage. Migmatite outcrops dominate most adjoining villages such as Kondo, Obatade, Tobalogbo and Alabi Oja at the northeastern part (Figure 1).

\section{Materials and Methods}

For geological and geomorphological studies of the area, field methods are crucial but are not efficient for large area coverage. In addition, relying on field data alone provides limited information on the persistence or spatial continuities of structures that are significant for groundwater occurrence. Hence, the present study integrated field mapping, remote sensing methods and application of geographical information system (GIS) techniques for extracting and inferring both the geology and the HGU from available information, maps and satellite imageries.

\section{Field Mapping}

The geological studies involved the conventional mapping of rock units and measurement of the structural elements on outcropping sections with the aid of compass clinometer. From this exercise, the available geology map of the 
area was updated and rock boundaries were accurately fixed. Location coordinates of rock types and rock structures such as fractures and faults and locally available information on other HGU including elevations and locations of surface water bodies were taken on site with the aid of Garmin eTrex GPS. These data were used as guides for interpreting information from the satellite images.

\section{Satellite Images}

Downloadable satellite imageries that were used for the present work are the shuttle radar terrain model (SRTM) bands of radar and the normalised difference vegetation index (NDVI) images from Landsat. These imageries are available globally and freely provided by National Aeronautics and Space Administration (NASA). The images were shot at the peak of dry season and were used for hydrogeological interpretation of the crystalline areas of the Ibarapa region.

\section{Radar}

The radar satellite images are readily applicable for interpretation of many significant parameters of hydrogeological importance such as terrain analysis, lineament mapping and geologic interpretation. The SRTM owned by NASA is a name given to the $\mathrm{C}$ and $\mathrm{X}$ radar bands that have a frequency range of approximately 3-10 GHz and a resolution of 25-90 m. The SRTM is the digital elevation model (DEM) of radar, which has strong application to the land surface relief and can give a 3D elevation impression of the study area. The absolute height accuracy of DEM is $16 \mathrm{~m}$, and the relative accuracy is $<10 \mathrm{~m}$. SRTM data in the form of DEMs are available globally between $60^{\circ} \mathrm{N}$ and $58^{\circ} \mathrm{S}$. The SRTM data have to be imported into ArcGIS for producing both the 2D and 3D terrain elevation from which the landform of the area is generated. It is also applicable for characterising the lineament and drainage network of the study area.

\section{Landsat Thematic Mapper (TM)}

Landsat TM is an advanced multispectral scanner used in Landsat 4 and 5 missions. It has seven ranges of wavelength specifications. Bands of red, green and blue (RGB) and thermal infra- red (TIR) were processed and used for specific hydrogeological investigations in the present work. The RGB Landsat bands have a ground resolution of $30 \mathrm{~m}$, while the TIR has a resolution of $120 \mathrm{~m}$ [14]. For structural characterisation of hard rock terrains, the TIR Landsat band is quite influential for delineation of structural (lineament) features such as folds, fractures, faults and foliation. Besides lineament features, the TIR band is also applicable for studying other hydrogeomorphologic features such as surface water flow and groundwater recharge $[15,16]$. These HGUs are distinguishable as a result of spatial differences in thermal characters of rocks. For example, lineaments that are conduits for water will produce traceable linear features due to the contrast in heat variations along the region of groundwater flow. In addition, in Landsat ETM, the three primary colours, namely blue, green and red, are assigned to $0.45-0.52,0.52-0.60$ and $0.63-0.69 \mu \mathrm{m}$ spectral bands, respectively. Hence, the vegetation of the area is processed from the NDVI since green vegetation reflects much light in the near infrared (NIR) band than in the red (RED) band. Hence, the difference between the two bands (i.e., NIR-RED) will give the vegetation index. The difference in reflection (known as DNs) of the NIR and RED bands is much greater for green vegetation than for bare soils, rock exposures, water bodies, etc. An image containing pixel values of the difference is termed a vegetation index image. However, due to a large range of spectral signature that can be generated from DNs, the difference is normalised by dividing it by the sum so that the range of NDVI values will lie between -1 and 1 . Hence, pixels with lush vegetation on an NDVI image that are often assigned to high values appear as whitish tones, while those with no or poor vegetation appear as dark grey to black tones.

The NDVI is applicable for detecting water-bearing lineaments. This application of NDVI assumes that vegetation respond to presence of water; hence, areas with plant lushness are characterised by water-containing fractures. This explanation is also used to detect groundwater recharge zones across the area. Nonetheless, for the present study, the NDVI is presented in colour composites for better image enhancement. The colour composite 
image of NDVI has an edge over the ordinary one, since interpretation in the latter considers light and dark tones for distinguishing features. However, in the colour composite image, the high-tone spots in NDVI are now seen as green colour spots, which represent locations with lush vegetation.

\section{Processing of Data}

The processing involved the applications of GIS techniques using Erdas Imagine and ArcGIS software for extracting data and for generating visual and digital thematic maps from the satellite images. In addition, the GIS is used for superimposition of the structural lineament map on the geological map to characterise the lineament units across the various bedrock terrains. The processed thematic maps produced for the entire site of investigation included the surface drainage network, structural lineament, DEM and NDVI. The first three maps, in addition to the geology map, were used to characterise the groundwater potential of the terrain, while the NDVI indicated the actual groundwater occurrence across the area. The peculiarity of the NDVI is that it reflects groundwater occurrence from vegetation response of the area if the area is irrigated naturally by underground waters. This is considered appropriate for the present study, since the area met the conditions for applying the NDVI as groundwater occurrence indicator. The area was not artificially irrigated, and the satellite imageries used were taken in the month of February at the peak of dry season in the Ibarapa region. This translates that the source of irrigation water is subsurface and not meteoric. The lushness and the orientations of vegetation on the ground indicate availability of groundwater along the direction of fracture orientation. It can also be extrapolated that the presence of riparian forest along surface water drainage such as river or stream is an indication of water seepage into the subsurface environment along that channel. Hence, the NDVI was also used to identify recharge zones across the study area.

In respect of lineament characterisation, it is known that all rock discontinuities such as fractures, faults and even rock contacts act as storage and conduits for water [17, 2], and are important hydrogeological units in basement complex terrains [19]. Hence, the attributes of lineaments including the linear density (or frequency), continuity (persistence) and direction of alignment were differentiated spatially. The persistence or continuity of lineament influences the degree of structural interconnectivity, which aids water transmission in any hard rock terrain. Conversely, the DEMs produced from SRTM were used in mapping the variations in terrain elevations across the study area. In addition, they were applicable for ascertaining the topographic features (landforms) associated with individual rock-type terrain in the area [18-20]. In addition, from the DEM, the surface water drainage and structural lineament were also traceable by incorporating the enhanced image into ArcGIS and Edras Imagine GIS software.

\section{Results and Discussion}

\section{Landforms}

The 2D and 3D DEMs of the study area are correspondingly shown in Figures $3 a$ and $3 b$. The geomorphology of the area is characterised by wide landforms contrast that included hills or inselbergs, highlands, lowlands and floodplains (Figures 3a and 3b). The hills and ridges are found at the central upper section of the area, spreading across most of the major towns, namely, Tapa, Ayete and Idere. Inselbergs are also associated with the northwest and northeast regions. These highly elevated landforms are separated by incision of valleys and lowlands that are drainage channels in the high-lying terrains. Most of these hills and ridges are porphyritic outcrops with elevations exceeding $300 \mathrm{~m}$ above the sea level. Terrain elevation drops from Idere toward the northeastern part to high ground or highlands that are mainly underlain by migmatite. There is also a small section of highlands at the western part of the gneissic bedrock terrain. The elevations of highlands are within 250-300 m. Terrains with elevations that range between 250 and $150 \mathrm{~m}$ are the lowlands. The underlying rock units that constitute the lowlands are gneisses and amphibolite. Lowland landforms are flat-lying plains and spread across the western and the southeastern parts of the area. Lastly, 


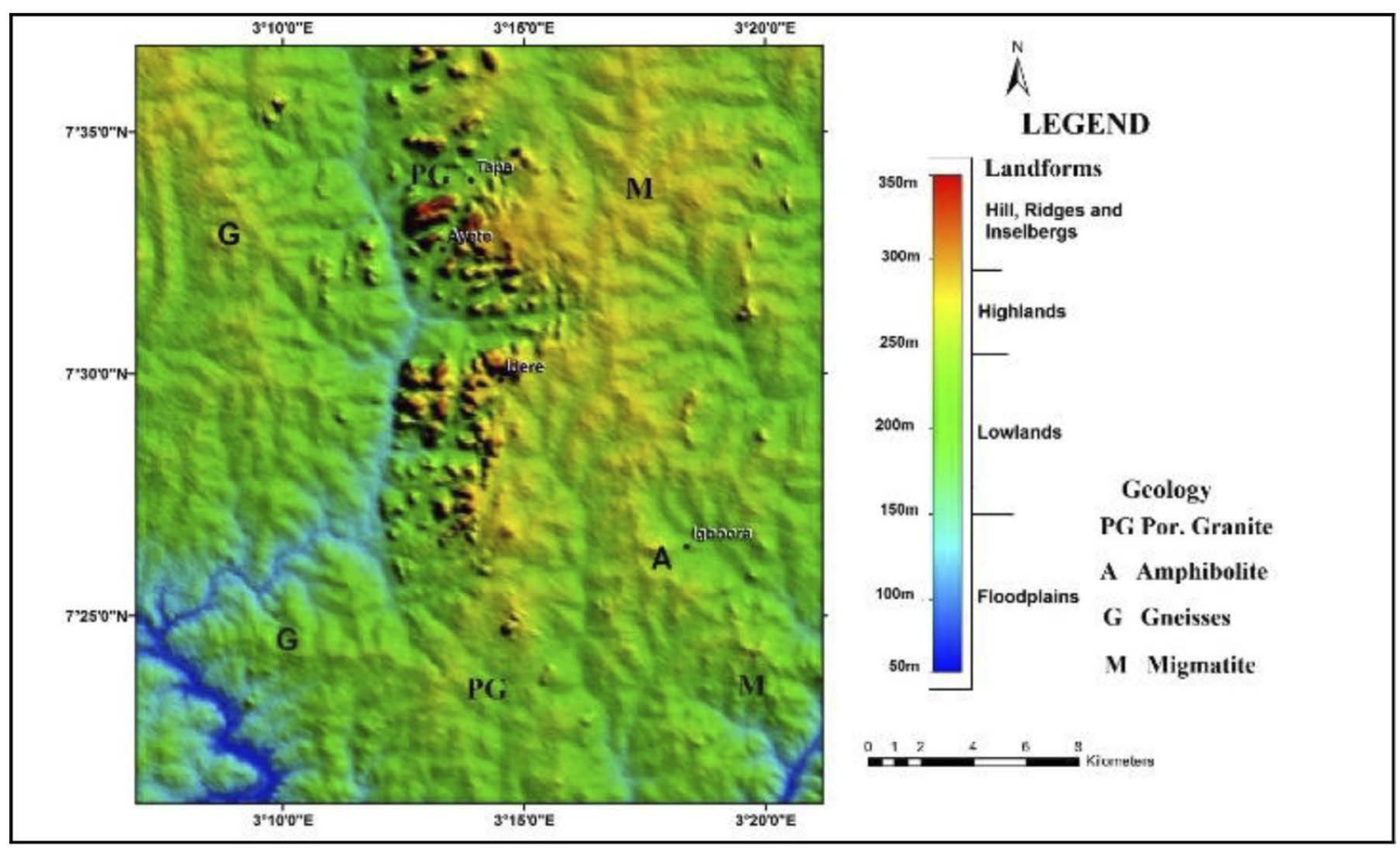

Figure 3a: $2 D D E M$ of the study area.

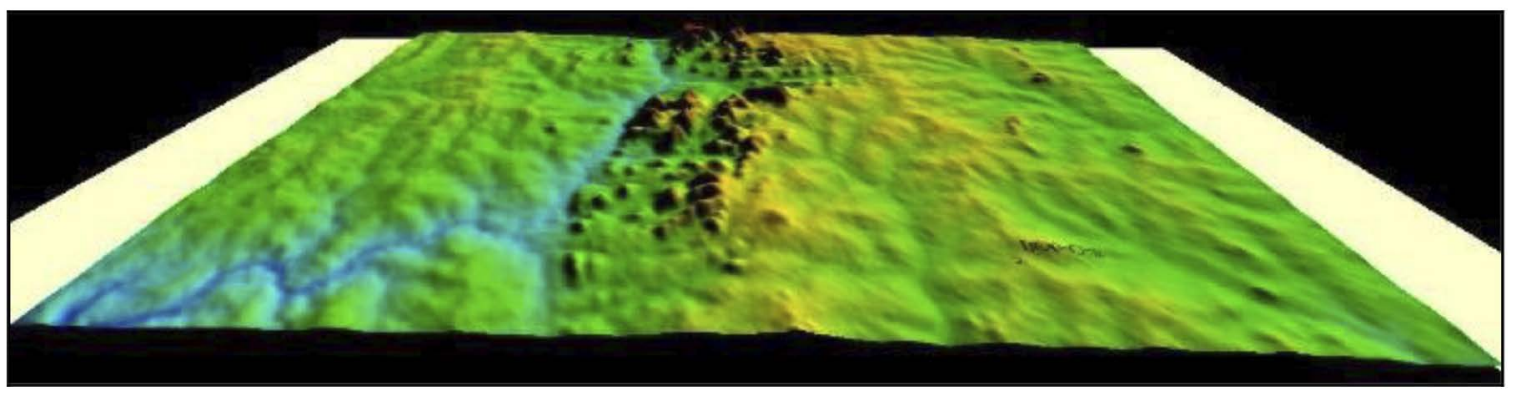

Figure 3b: 3D DEM of the study area.

the floodplains are land depression terrains with elevation less than $150 \mathrm{~m}$. Floodplains are prone to flooding and sediment deposition from transported regolith of the upland areas. In terms of area coverage, the floodplains occupy the smallest area and are restricted to small sections in the southwest and southeast parts of the area, the former floodplain being larger than that on the migmatitic terrain at the southeast (Figure 3a).

Usually, the high topographic terrains are regarded as recharge areas characterised by deeper water table and high hydraulic gradient. Low-lying areas are normally the discharge zones where the water table is shallow and close to the surface environment [1]. Hence, based on the topographic consideration alone, areas underlain by porphyritic granite and migmatite are the recharge points, while amphibolitic and gneissic terrains are expected to have better groundwater potential with respect to groundwater yield and sustainability.

\section{Drainage and Watershed}

The drainage pattern is dendritic (Figure 4) as typical of basement areas marked by high contrast in relief. The surface drainage network consists of rivers, namely, Iworo, Ayin, Afo-Ape, Opeki, Aboluku and Ofiki. However, River Ofiki is the most prominent river that traverses and drains large part of the northern area including the granitic terrain at the central region, part of 


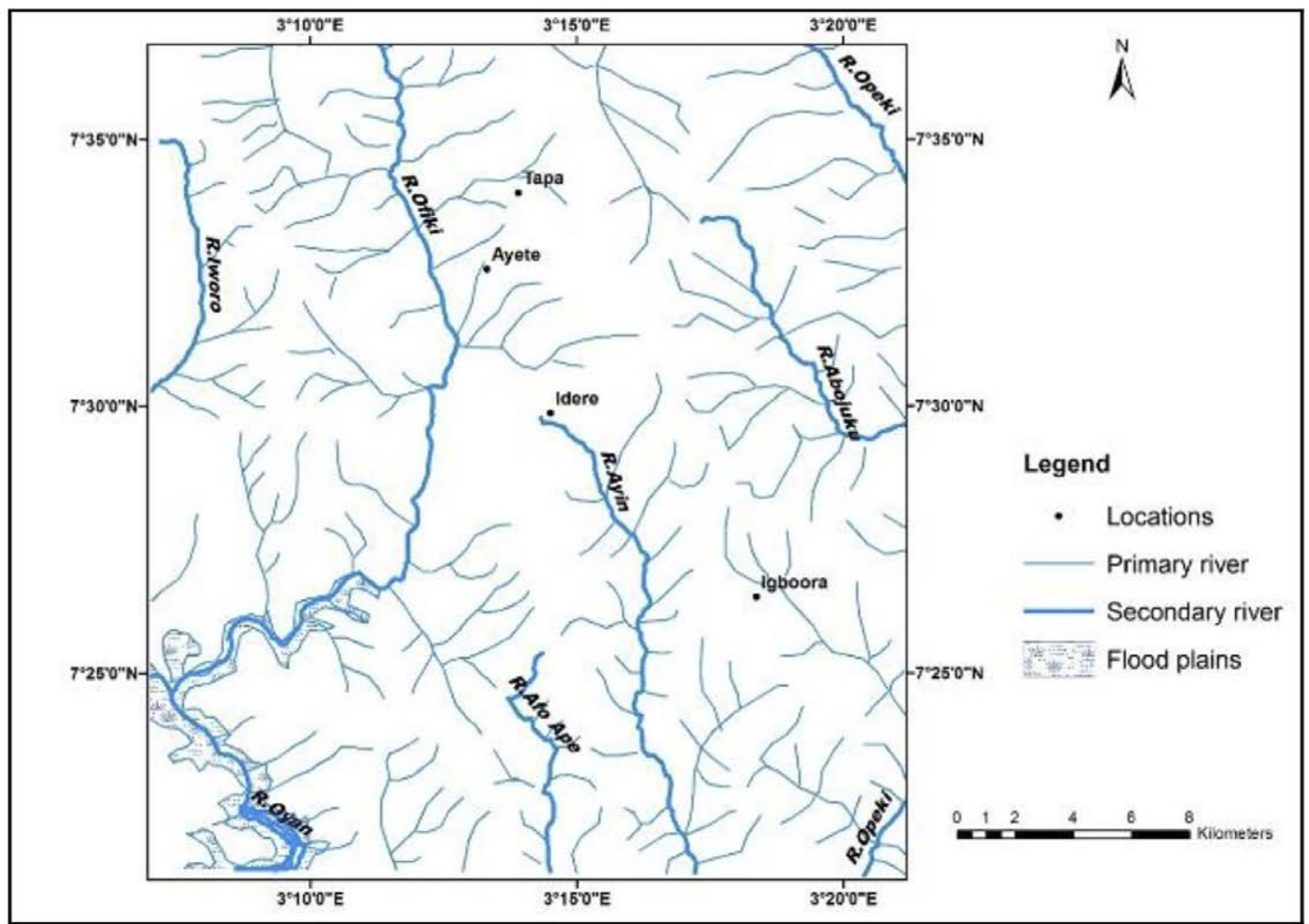

Figure 4: Drainage pattern of the study area.

area underlain by banded gneiss at the WNW region and up to the migmatitic terrain boundary north of Idere. The drainage pattern breaks the entire study area into different interfluves whereby each interfluve is an eroded inland area drained by a river network. By connecting interfluves that drains into the same secondary river, the entire area was partitioned into five watershed units that were named after the secondary river draining the area. These include Iworo at the NW, Ofiki at the central west, AfoApe at the south central, Ayin at the south central east and lastly the Aboluku-Opeki watershed extending from the east to the northeast. The Iworo watershed is underlain by banded biotite gneiss steeply dipping west. River Iworo flows along the $\mathrm{N}-\mathrm{S}$ direction, along the strike of the rock foliation. River Ofiki, which is the longest and the most prominent river, merges into River Oyan at the southwestern part of the study area. The tributaries of River Ofiki drain most part of inland regions of Oye-Igangan, Tapa, Ayete and Idere towns. This watershed has the most contrasting relief, ranging from the centrally high topographic landforms of porphyritic granite and porphyroblastic gneiss that peak at $350 \mathrm{~m}$ above the sea level. The AfoApe watershed is a minor watershed located at the central southern part of the study area that is underlain by porphyritic granite. It is a lowland with elevation below $150 \mathrm{~m}$ above the sea level. However, the central portion is dominated by inselbergs as well as relief up to $300 \mathrm{~m}$ above the sea level. The Ayin watershed covers the main township of Igbo-Ora and Idere with their adjoining areas. This region is the most complex in terms of rock types. The northern section of the Ayin watershed is underlain by granite with the associated high-rising landforms. This area encompasses Idere town and its environs. At the west, the underlying rock type is migmatite; the southwestern region is underlain by amphibolite and lastly, the Aboluku-Opeki watershed is mainly underlain by migmatite.

\section{Structural Lineaments}

The structural lineament thematic map is presented in Figure 5. This map revealed that lineaments are mainly of rectilinear type, which 


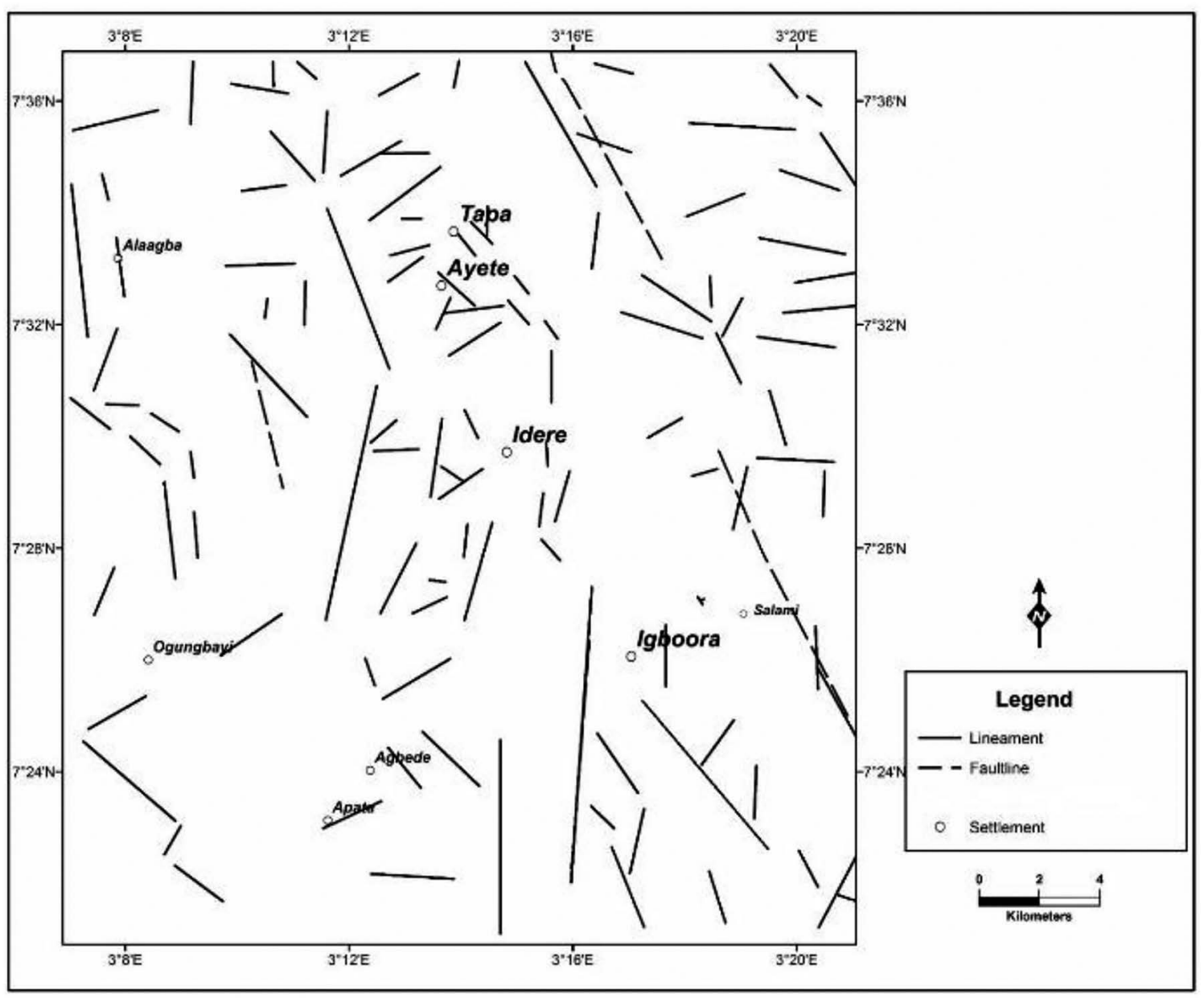

Figure 5: Structural map of the study area.

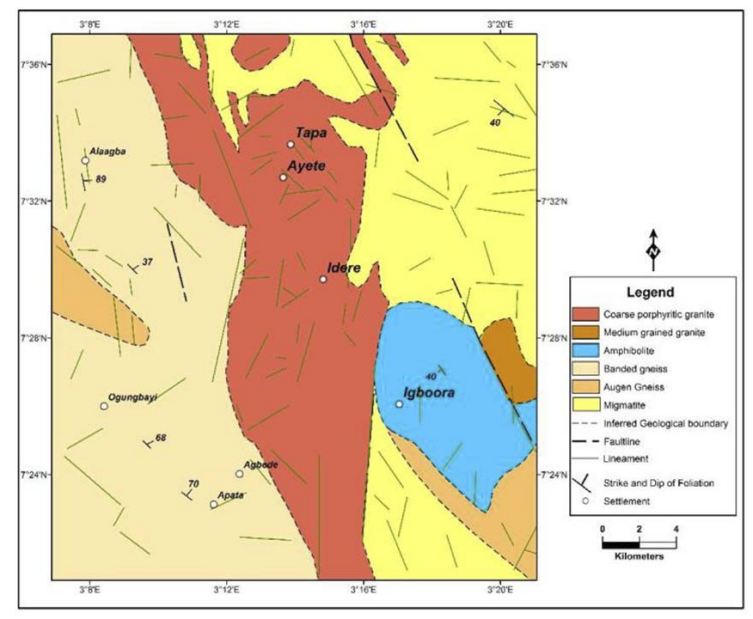

Figure 6: Updated geological map of the study area with structural lineaments.

indicates the brittle nature of the hard rocks that underlain the area. However, evidence of ductile behaviour represented by curvilinear fractures existed at the south of Alagba at the western part of the study area, which is underlain by biotite gneiss where foliation planes dip almost vertically (Figure 6). Obviously, there are spatial disparities in lineament attributes across the study area (Figure 5). The variation in structural units across the various hard rock terrains is shown by the superimposition of lineaments on the geology map in Figure 6.

The degree of rock brittleness is more intense at the central region underlain by porphyritic granite, which is characterised by high topographic landforms (Figures 3 and 6). These granitic terrains are associated with more numerous but short-length lineaments of linear density $0.25 \mathrm{~km}^{-1}$ compared to other parts of the study area (Figure 5). Notwithstanding, lineaments within the migmatitic and gneissic terrains, correspondingly at the northeast 
Amphibolite

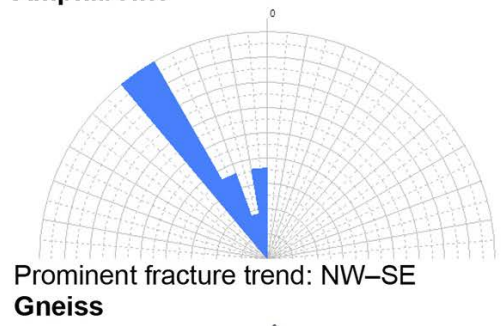

Gneiss

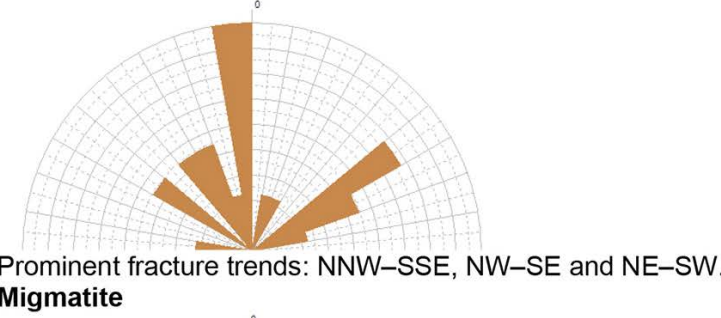
Migmatite

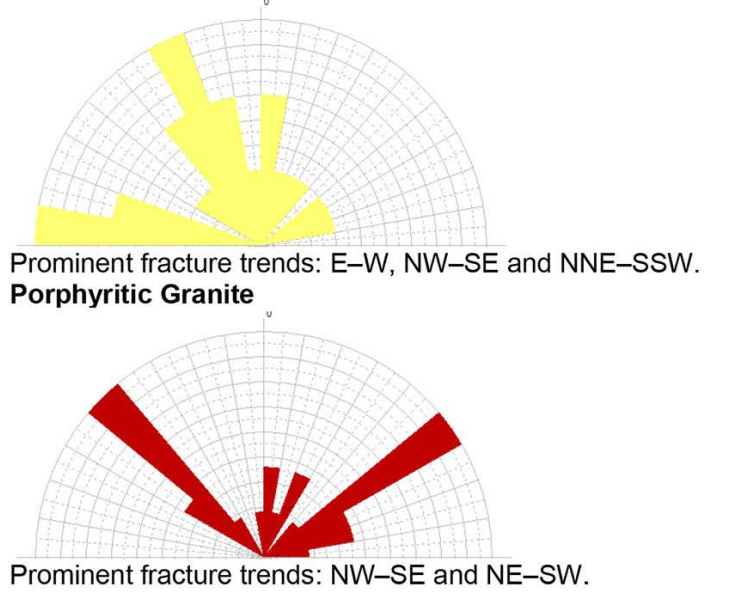

Figure 7: Rose diagrams of lineaments/fractures obtained for the various bedrocks, illustrating the prominent orientations.

and northwest areas, were dominated by more extensive and persistent structural units but at lower densities of 0.18 and $0.17 \mathrm{~km}^{-1}$, respectively. Similarly, at the southern part of the area, porphyritic granitic terrains at the south-central portion are also characterised by higher lineament concentration with a density of $0.14 \mathrm{~km}^{-1}$ compared to that of 0.06 and $0.10 \mathrm{~km}^{-1}$ obtained for southwest and southeast portions underlain by gneiss and amphibolite, respectively.

Furthermore, Figure 6 revealed that most of the mega fractures occurred at rock contacts. In fact, River Ofiki, which is the major river that drains the study area, traverses the boundary between porphyritic granite and gneiss at the western part (Figures 3-6). In addition, at the east, occurrences of mega-linear features were associated with rock contacts between porphyritic granite and migmatite at the north and in-between porphyritic granite, migmatite and amphibolite at the south-east area. Porphyritic granitic terrains that are associated with a high fracture frequency are characterised by disjointed and less persistent (or mega) lineaments compared to gneissic and migmatitic terrains. However, at porphyritic granite boundaries with other rocks, the lineament persistence is large (Figure 6).

The orientations of linear features as shown in rose diagrams in Figure 7 are multidimensional except on amphibolite where the major fracture's trend is along the NW. In gneisses, the prominent fractures' trends are NNW-SSE, NW-SE and NE-SW. Likewise, migmatite bedrocks are characterised by three dominant linear trends, which are E-W, NW-SE and NNE-SSW, and porphyritic granite bedrocks by two major trends, which are NW-SE and NE-SW.

\section{Vegetation Index}

The NDVI colour composite of the area is presented in Figure 8. Pockets of localised groundwater zones represented by lush vegetation occur in some parts of the area. In addition, zones of recharge or water seepage signified by riparian forests are found to be associated along some river channels. However, the attributes of these groundwater occurrences are diverse and are symbolised by rings and arrows as shown in Figure 8. The white rings represent localised areas of groundwater occurrences. The white arrows show groundwater zones that are prominently controlled by the mega structural lineament in that area, while the red arrows indicate surface water channels along which water seepage or groundwater recharge occurs. The clustered nature of lush vegetation demarcated by white rings revealed that groundwater is found in diverse lineament trends in these areas (Figure 8). On the other hand, there are evidences of occurrences of groundwater in major lineaments at some locations. This is prominent around the Alagba area at the northwest region, where lush vegetation is linearly oriented along the major structural trend in that area (Figure 8). This conspicuous groundwater occurrences trend NW-SE (Figure 8), and this trend is the strike of the mega fracture in that location 


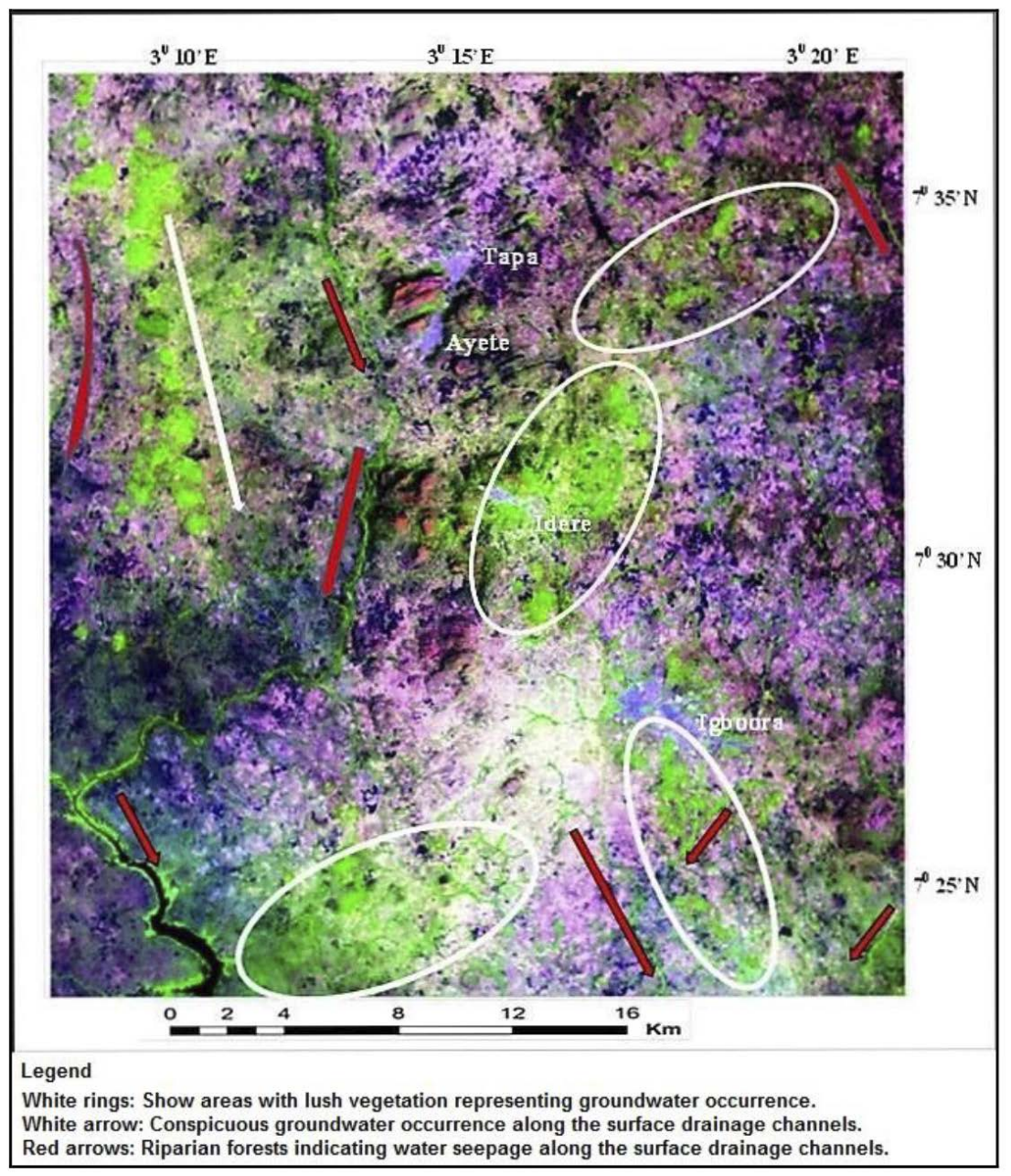

Figure 8: Groundwater indication from colour composite NDVI image.

(Figure 6). In this region, the underlying hard rock is banded gneiss, the foliation plane dips vertically and the direction of mineral alignment is NW-SE (Figure 2). The direction of alignment of the groundwater occurrence is the same direction at which the mineral constituents are aligned in this area (Figure 8). This revealed that the directions of mineral alignment in foliated rocks are likely zones of structural weakness for fracture generation and potential zones of groundwater occurrence in the hard rock terrain. The topography of the area is lowmoderate-lying terrains, comprising valleys and moderate highland ridges that are oriented along the strike of rock foliation (Figures 2 and 3). The prominent groundwater occurrence in the area is oriented along the NW-SE strike ridge in-between rivers Iworo and Ofiki (Figures 4 and 8). This groundwater zone is re- charged by River Ofiki due to evidence of water seepage along its channel (Figure 8).

Conversely, riparian forests, which are indicators of water seepage along the surface drainage network, are found across the area (Figure 8), although it is mostly prominent along River Ofiki, which drains substantial area of the northern section and traverses rock boundaries between banded gneiss and porphyritic granite to migmatite boundary at the north of Idere (Figures 4, 6 and 8). Likewise from Figure 8 , it is obvious that rock boundaries are also viable groundwater zones in the area due to lush vegetation associated with zones of rock contacts. This is particularly noticeable at the centre portion around Idere and other locations at the southern parts (Figure 8).

Apart from terrains around rock contact zones, groundwater occurrences are found to be con- 
fined to terrains underlain by amphibolite and gneiss (Figures 2 and 8). The topographic features in amphibolitic and gneissic terrains are low-to-medium-lying terrains (Figure 3). Conversely, groundwater occurrence is at the lowest at the north-north and most parts of the northeastern region of the study area (Figure 8), which is associated with high topographic landforms (Figure 3). These high-lying terrains are underlain by porphyritic granite and migmatite (Figure 2), and the terrains are characterised by generation of thin riparian forests and sparse vegetation response (Figure 8). Hence, locations of low-lying areas underlain by amphibolite and gneiss are the discharge zones, while the high-lying areas of porphyritic granitic and migmatitic terrains are the recharge zones within the study area. This is buttressed by the fact that the fracture density is high on granitic and migmatitic terrains (Figure 6). Although the persistence of fractures is low on the former terrain, there are extensive and more persistent lineaments associated with migmatitic terrains (Figure 6). Furthermore, despite the extensive and high fracture frequency associated with terrains underlain by porphyritic granite and migmatite (Figure 6), groundwater occurrence is still poor (Figure 8). This is typified by sparse vegetation cover and infrequency of riparian forest at the north-north and northeastern regions (Figures 2 and 8). This confirms that the infiltrated water through the numerous fractures is summarily transmitted into the adjacent low-lying terrains underlain by amphibolite and gneiss. In addition, the fact that these regions are associated with sparse vegetation suggests that the water level is far from the land surface. Notwithstanding, there are few small-sized water-laden fracture distributions scattered across the migmatitic terrain at the northeastern part (Figure 8). More so, it is also expected that the rates of overland and interflow will be high in high topographic areas underlain by porphyritic granite and migmatite, so that meteoric water is transmitted into adjacent low-lying areas underlain by amphibolite and gneiss (Figures 2 and 3 ).

Table 1 gives the concise details of the facts extracted from the thematic maps and the interpreted groundwater occurrence under each watershed units with their respective under- lying bedrocks. For example, the Iworo watershed that is underlain by banded gneiss at the NW region is characterised by strike ridges with adjacent valley landforms (Figure 3a). The lineaments strike the NNW-SSE direction, and the foliation dips vertically (Figure 2). Groundwater occurrence is conspicuous along the strike of the foliation in this region. The Ofiki watershed traverses large area with lot of diverse topographic features ranging from lowlands at the WNW region to granitic highlands at the north-central region that extends through Tapa, Ayete and toward the migmatitic terrain boundary north of Idere. Groundwater occurrences are indicated by evidences of groundwater recharge from generation of riparian forests along the main channel of river Ofiki (Figure 8). However, groundwater zones are in variable directions and less linearly oriented at rock contact zones around Idere at the north-central section. The Ayin and Afo-Ape watersheds are mainly granitic terrains but also extend to part of rock contact zones in-between migmatite, augen gneiss and amphibolite (Figures 2 and 4). Groundwater occurrence is fair at rock contact zones with minor recharge along river Ayin (Figure 8). Lastly, Opeki and Aboluku watersheds are mainly underlain by migmatite at the NE and amphibolite at the SE. Groundwater occurrence is localised in small compartments. Rock contact zones also show fair prospect for groundwater.

\section{Conclusion}

The occurrence of groundwater in the study area is guided by topographic and structural influences. The clustered groundwater occurrence at rock contact zones showed that the orientations of the water-laden fractures are multidirectional. However, there are possibilities of locating major groundwater zones along mega lineaments whose structural outline is defined by the alignment of local rock foliation. This method of research is readily applicable for demarcating zones of groundwater potential for further groundwater development in hard rock terrains characterised by diverse geological and geomorphological settings. 
Table 1: Attributes of groundwater occurrence interpreted from HGU.

\begin{tabular}{|c|c|c|c|c|c|c|}
\hline $\mathbf{S} / \mathbf{n}$ & $\begin{array}{l}\text { Watershed } \\
\text { units, region }\end{array}$ & $\begin{array}{l}\text { Underlying } \\
\text { rock type }\end{array}$ & Landform & $\begin{array}{c}\text { Lineament } \\
\text { characterisation }\end{array}$ & $\begin{array}{l}\text { Vegetation } \\
\text { response }\end{array}$ & $\begin{array}{l}\text { Interpretation } \\
\text { of groundwater } \\
\text { occurrence }\end{array}$ \\
\hline 1 & $\begin{array}{l}\text { Iworo, } \\
\text { northwestern } \\
\text { section }\end{array}$ & $\begin{array}{c}\text { Banded and } \\
\text { augen gneisses }\end{array}$ & $\begin{array}{l}\text { Moderate } \\
\text { highland, } \\
\text { strike } \\
\text { ridges with } \\
\text { adjacent } \\
\text { parallel } \\
\text { valleys }\end{array}$ & $\begin{array}{l}\text { NNW-SSE } \\
\text { trending } \\
\text { fractures, some } \\
\text { of which are } \\
\text { curvilinear, } \\
\text { indicating mega- } \\
\text { fold structure }\end{array}$ & $\begin{array}{l}\text { Linearly } \\
\text { oriented lush } \\
\text { vegetation along } \\
\text { the NNW-SSE } \\
\text { trendingfracture }\end{array}$ & $\begin{array}{l}\text { Abundant } \\
\text { groundwater } \\
\text { occurrence. } \\
\text { Groundwater } \\
\text { discharge is } \\
\text { directional and } \\
\text { found in the } \\
\text { NNW-SSE fractures } \\
\text { that trend along the } \\
\text { strike of the local } \\
\text { foliation in the area }\end{array}$ \\
\hline \multirow[t]{2}{*}{2} & $\begin{array}{l}\text { Ofiki-Oyan, } \\
\text { southwestern } \\
\text { section }\end{array}$ & Banded gneiss & $\begin{array}{l}\text { Lowlands } \\
\text { and } \\
\text { floodplains }\end{array}$ & $\begin{array}{l}\text { Less dense but } \\
\text { persistent along } \\
\text { which the river } \\
\text { flow }\end{array}$ & $\begin{array}{l}\text { Riparian forests } \\
\text { along the } \\
\text { river channel } \\
\text { and clustered } \\
\text { vegetation at } \\
\text { rock contact } \\
\text { zones at the } \\
\text { south }\end{array}$ & $\begin{array}{l}\text { Groundwater } \\
\text { recharge along } \\
\text { the river channels. } \\
\text { Groundwater } \\
\text { occurrence at } \\
\text { variable directions } \\
\text { in the rock contact } \\
\text { zone at the south }\end{array}$ \\
\hline & $\begin{array}{l}\text { Ofiki, middle- } \\
\text { belt northern } \\
\text { section }\end{array}$ & $\begin{array}{l}\text { Porphyritic } \\
\text { granite }\end{array}$ & $\begin{array}{l}\text { Hills and } \\
\text { inselbergs } \\
\text { with } \\
\text { adjacent } \\
\text { valley } \\
\text { incisions }\end{array}$ & $\begin{array}{c}\text { Fracture } \\
\text { frequency is high } \\
\text { but persistence } \\
\text { is low, typifying } \\
\text { high degree of } \\
\text { rock brittleness. } \\
\text { Fractures } \\
\text { with variable } \\
\text { orientations along } \\
\text { the NEE-SWW, } \\
\text { NNE-SSW and } \\
\text { NE-SW directions }\end{array}$ & $\begin{array}{l}\text { Sparse } \\
\text { vegetation along } \\
\text { the river bank. } \\
\text { Lush-clustered } \\
\text { vegetation at } \\
\text { the rock contact } \\
\text { zone at the } \\
\text { middle section } \\
\text { around Idere }\end{array}$ & $\begin{array}{l}\text { High fracture } \\
\text { density but poor } \\
\text { groundwater } \\
\text { occurrence. } \\
\text { Recharge zone with } \\
\text { deep water table, } \\
\text { beyond the reach of } \\
\text { plants. Groundwater } \\
\text { occurrence in } \\
\text { variable directions } \\
\text { within the contact } \\
\text { zones at Idere }\end{array}$ \\
\hline 3 & $\begin{array}{l}\text { Ayin-Afo Ape, } \\
\text { middle-belt } \\
\text { southern } \\
\text { section }\end{array}$ & $\begin{array}{l}\text { Porphyritic } \\
\text { granite and } \\
\text { rock contacts }\end{array}$ & $\begin{array}{l}\text { Granitic } \\
\text { ridges at the } \\
\text { upper middle } \\
\text { section. } \\
\text { Lowlands } \\
\text { at the lower } \\
\text { middle } \\
\text { section }\end{array}$ & $\begin{array}{l}\text { Fairly numerous } \\
\text { and more } \\
\text { persistent } \\
\text { fractures } \\
\text { compared to the } \\
\text { upper granitic } \\
\text { terrain }\end{array}$ & $\begin{array}{l}\text { Presence of } \\
\text { sparse riparian } \\
\text { forests along } \\
\text { the channels } \\
\text { but the weight. } \\
\text { Fairly clustered } \\
\text { vegetation } \\
\text { at the rock } \\
\text { boundary zones } \\
\text { in the south }\end{array}$ & $\begin{array}{l}\text { Low water seepage } \\
\text { along river channels } \\
\text { and tributaries. } \\
\text { Fair groundwater } \\
\text { occurrence at rock } \\
\text { contact zones }\end{array}$ \\
\hline 4 & $\begin{array}{l}\text { Opeki and } \\
\text { Aboluku, } \\
\text { northeastern } \\
\text { section }\end{array}$ & $\begin{array}{l}\text { Predominantly } \\
\text { underlain by } \\
\text { migmatite }\end{array}$ & $\begin{array}{l}\text { Highlands } \\
\text { with } \\
\text { inselbergs }\end{array}$ & $\begin{array}{l}\text { Numerous and } \\
\text { extensively } \\
\text { persistent } \\
\text { fractures aligned } \\
\text { toward E-W and } \\
\text { NW-SE trends }\end{array}$ & $\begin{array}{l}\text { Scarce, a few } \\
\text { small-to- } \\
\text { medium-sized } \\
\text { pockets of } \\
\text { scattered } \\
\text { vegetation. } \\
\text { Riparian forest } \\
\text { is scarce }\end{array}$ & $\begin{array}{c}\text { Groundwater } \\
\text { recharge area. Depth } \\
\text { to water table is } \\
\text { deep }\end{array}$ \\
\hline & $\begin{array}{l}\text { Opeki and } \\
\text { Aboluku, } \\
\text { southeastern } \\
\text { section }\end{array}$ & $\begin{array}{l}\text { Migmatite, } \\
\text { amphibolite } \\
\text { and rock } \\
\text { contact zones }\end{array}$ & $\begin{array}{l}\text { Low-to- } \\
\text { medium- } \\
\text { lying } \\
\text { landform }\end{array}$ & $\begin{array}{l}\text { Fractures fairly } \\
\text { dense and more } \\
\text { persistent along } \\
\text { rock contacts }\end{array}$ & $\begin{array}{l}\text { Clustered at } \\
\text { rock contacts } \\
\text { and riparian } \\
\text { forests are fairly } \\
\text { present }\end{array}$ & $\begin{array}{l}\text { Groundwater } \\
\text { discharge zones at } \\
\text { rock contact and on } \\
\text { amphibolite with } \\
\text { variable orientation }\end{array}$ \\
\hline
\end{tabular}




\section{References}

[1] Fetter, C.W. (2007): Applied hydrogeology. 2nd edition. USA: Merrill Publishing Company.

[2] Akanbi, O.A. (2017): Hydrogeological Characterisation of Crystalline Basement Aquifers of part of Ibarapa Area, Southwestern Nigeria. Ph. D. Thesis. Ibadan-Nigeria: University of Ibadan 2017; 312 p.

[3] Pierce, L.L., Walker, J., Dowling, T.L., McVicar, T.R, Hatton, T.J., Running, S.W., Coughlan, J.C. (1993): Ecohydrological Changes in the Murray-Darling Basin. III. A Simulation of Regional Hydrological Changes. Journal of Applied Ecology, 30(2), pp. 283-94.

[4] Tweed, S.O., Leblanc, M., Webb, J.A. and Lubczynski, M.W. (2007): Remote sensing and GIS for mapping groundwater recharge and discharge areas in salinity prone catchments, southeastern Australia. Hydrogeology Journal, 15(1), pp. 75-96.

[5] Philip G., Singhal, B.B.G. (1992): Importance of geomorphology for hydrogeological study in hard rocks terrain, an example from Bilhar Plateau through remote sensing. Indian Journal of Earth Sciences, 19(4), pp. 177-188.

[6] Sreedevi, P.D., Subrahmanyam, K., Ahmed, S. (2005): Integrated approach for delineating potential zones to explore for groundwater in the Paguru River Basin, Cuddapah District, A.P., India. Hydrogeology Journal, 13(3), pp. 534-543.

[7] Sander, P. (2007). Lineaments in groundwater exploration: a review of applications and limitations. $\mathrm{Hy}$ drogeology Journal, 15(1), pp. 71-74.

[8] Wright, E.P. (1992): The hydrogeology of crystalline basement aquifers in Africa. In: Hydrogeology of crystalline basement aquifers in Africa, Wright, E.P., Burgess, W.G. (eds.) Geological society special publication No. 66. Geological society: London.

[9] Nigeria's 2006 Population Census Arranged by State [online], Available on: <http://www.nigerianmuse.com/./nigeria-2006-population-census-arranged-by-state-wikipe>

[10] Tartiyus, E.H., Mohammed, I.D., Amade, P. (2015): Impact of Population Growth on Economic Growth in Nigeria (1980-2010). Journal of Humanities and Social Science (IOSR-JHSS), 20(4), 115-123. DOI: 10.9790/0837-2045115123.
[11] Offodile, M.E. (2002): Ground water study and development in Nigeria. 2nd edition. Jos: Mecon geology and engineering services limited.

[12] Jayeoba, A., Oladunjoye, M.A. (2013): Hydro-geophysical evaluation of groundwater potential in hard rock terrain of southwestern Nigeria. RMZ-Materials and Geo-environment, 60, pp. 271-284.

[13] Akanbi, O.A. (2016): Use of vertical electrical geophysical method for spatial characterisation of groundwater potential of crystalline crust of Igboora area, southwestern Nigeria. International Journal of Scientific and Research Publications, 6(3), pp. 399-406.

[14] Meijerink, A.M.J. (2007): Remote sensing applications to groundwater. Paris: United Nations Educational Scientific and Cultural Organization (UNESCO).

[15] Shaban, A., Khawlie, M., Abdalla, C. (2006): Use of GIS and remote sensing to determine recharge potential zones; the case of occidental Linanon. Hydrogeology Journal, 14(4), pp. 433-443.

[16] Granados-Olivas, A., Corral Diaz, R. (2003): Fracture trace and alignment analysis for groundwater characterization. Hydrology of Mediterranean and Semiarid regions. IAHS Publ. 278 (Montpellier Symposium), pp. 24-28.

[17] Singhal, B.B.S., Gupta, R.P. (1999): Applied hydrogeology of fractured rocks. Dordrecht, Netherlands: Kluwer Academic Publishers; 400 p.

[18] Leblanc, M., Razack, M., Dagorne, D., Mofor, L., Jones, C., (2003): Application of Meteosat thermal data to map soil infiltrability in the central part of the Lake Chad Basin, Africa. Geophysical Research Letter, 30(19), Art. No. 1998.

[19] [19] Münch, Z., Conrad, J. (2007): Remote sensing and GIS based determination of groundwater dependent ecosystems in the Western Cape, South Africa. Hydrogeology Journal, 15 (1), pp. 9-28.

[20] Robinson, C.A., Werwer, A., El-Baz, F., El-Shazly, M., Fritch, T., Kusky, T. (2007): The Nubian aquifer in south-west Egypt. Hydrogeology Journal, 15(1), pp. 33-45. 